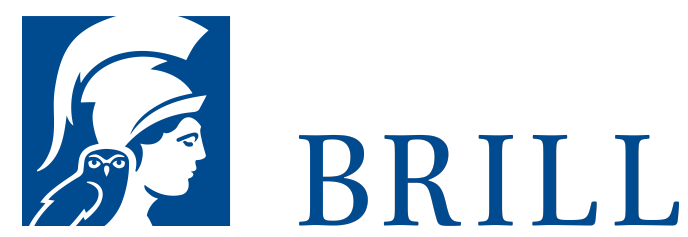

\title{
Marriage Laws in the Bible and the Talmud
}

Author: L.M. Epstein

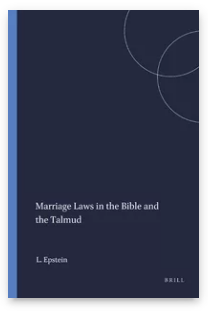

\section{Language: \\ English}

Subjects: Law, Ancient Near

East and Egypt, Ancient

Judaism, Biblical Studies, Biblical Interpretations, Biblical Studies, Jewish Law, Jewish Studies

Publisher: Brill

\section{Series:}

Harvard Semitic Studies, Volume: 12

E-Book (PDF)

Released online: 25 Feb 2020

ISBN: 978-9004-38442-2 List price USD $\$ 66.00$

Paperback Publication date: o1 Jan 1942 ISBN: 978-9004-41153-1 List price USD $\$ 66.00$ 
For more information see brill.com

Order information: Order online at brill.com +44330 333 0049 | customerservices@brill.com Submission information: brill.com/authors

Titles published by Brill | Fink, Brill | mentis or Brill | Schöningh: +49(o)715413279216| brill@brocom.de 